\title{
Synthesis of Four Pentacyclic Triterpene-Sialylglycopeptide Conjugates and Their Affinity Assays with Hemagglutinin
}

\author{
Mei Luo, Ximin Wu, Yiming Li * and Fujiang Guo *D \\ School of Pharmacy, Shanghai University of Traditional Chinese Medicine, Shanghai 201203, China; \\ aluofor@126.com (M.L.); wxm@shutcm.edu.cn (X.W.) \\ * Correspondence: ymli@shutcm.edu.cn (Y.L.); gfj@shutcm.edu.cn (F.G); Tel.: +86-215-132-2181 (F.G.)
}

\begin{abstract}
Influenza outbreaks pose a serious threat to human health. Hemagglutinin (HA) is an important target for influenza virus entry inhibitors. In this study, we synthesized four pentacyclic triterpene conjugates with a sialylglycopeptide scaffold through the $\mathrm{Cu}(\mathrm{I})$-catalyzed alkyne-azide cycloaddition reaction (CuAAC) and prepared affinity assays of these conjugates with two HAs, namely H1N1 (A/WSN/1933) and H5N1 (A/Hong Kong/483/97), respectively. With a dissociation constant $\left(K_{\mathrm{D}}\right)$ of $6.89 \mu \mathrm{M}, \mathrm{SCT}-$ Asn-betulinic acid exhibited the strongest affinity with the H1N1 protein. Furthermore, with a $K_{\mathrm{D}}$ value of $9.10 \mu \mathrm{M}$, SCT-Asn-oleanolic acid exhibited the strongest affinity with the $\mathrm{H} 5 \mathrm{~N} 1$ protein. The conjugates considerably enhanced antiviral activity, which indicates that pentacyclic triterpenes can be used as a ligand to improve the anti-influenza ability of the sialylglycopeptide molecule by acting on the HA protein.
\end{abstract}

Keywords: influenza virus; pentacyclic triterpenes; sialylglycopeptide; hemagglutinin

check for

updates

Citation: Luo, M.; Wu, X.; Li, Y.; Guo, F. Synthesis of Four Pentacyclic Triterpene-Sialylglycopeptide Conjugates and Their Affinity Assays with Hemagglutinin. Molecules 2021, 26, 895. https://doi.org/10.3390/ molecules26040895

Academic Editor: Lothar Elling

Received: 18 January 2021

Accepted: 3 February 2021

Published: 8 February 202

Publisher's Note: MDPI stays neutral with regard to jurisdictional claims in published maps and institutional affiliations.

Copyright: (c) 2021 by the authors. Licensee MDPI, Basel, Switzerland. This article is an open access article distributed under the terms and conditions of the Creative Commons Attribution (CC BY) license (https:// creativecommons.org/licenses/by/ $4.0 /)$.

\section{Introduction}

Influenza is a highly contagious acute upper respiratory disease caused by influenza viruses. Seasonal influenza causes 29-65 million deaths annually [1], and large outbreaks can be even more severe [2]. Current prevention and treatment methods mainly include vaccines and drugs. However, antiviral drugs are typically used for treatment because vaccines have a long development time, high cost, and reduced effectiveness resulting from antigen drift [3]. Currently, depending on the glycoproteins and enzymes involved when the virus infects the host cell [4], the main targets include hemagglutinin (HA), matrix proteins (M1), proton ion channel proteins (M2), RNA-dependent RNA polymerase $(\mathrm{RdRp})$, nucleoprotein (NP), nonstructural protein 1 (NS1), nuclear export protein (NS2), neuraminidase (NA), and polymerase proteins (PB1, PB2 and PA) [5]. Two types of drugs have been developed to hinder influenza virus infection. Oseltamivir, zanamivir, and peramivir act on NA, and amantadine and rimantadine act on the M2 ion channel protein. However, new antiviral drugs should be continuously developed because of drug side effects and viral resistance [6,7].

HA, a trimer, is composed of HA1-containing sialic acid (SA) binding sites and HA2 anchored on the surface of the virus [8]. HA1 mediates attachment to SA receptors on the target cell, and HA2 undergoes extensive conformational changes, which contribute to membrane fusion and the release of viral genetic materials into host cells [9]. According to the results of a study on antigen profiles, with the exception of the SA receptor-binding domain, mutations in HA1 are tolerable without affecting the overall function of HA [10]. Thus, HA is a potential target for antiviral drugs.

Sialylglycopeptide (SGP), with two SA fragments at the molecule end, is a form in which SA exists as a glycopeptide [11] and can be prepared in large quantities from egg yolk [12]. Studies have revealed that in influenza A virus infection, HA first binds to the NeuAc $\alpha(2-6)$ Gal residues of the sugar chain on the host cell surface [13]. SGP with this residue has studied widely studied; Bovin et al. reported the effective inhibitory effect of 
the SGP polymer with polyacrylamide on influenza virus infection [14]. Considering the safety of polyacrylamide for host cells, chitosan — which is a safe biocompatible materialis used to synthesize chitosan-SGP complexes [15]. SGP is also used to form conjugates with human serum albumin [16], glycopolymers [17], and erythropoietin [18]. SGP has a representative $\mathrm{N}$-sugar chain structure for protein glycosylation. This chain is a vital intermediate for the synthesis of glycopeptides and glycoproteins with a single glycoform structure [19-24], and it can avoid complex synthesis processes [25,26]. Grafting SA to other biologically active molecules, such as triterpenes, can also increase antiviral activity $[27,28]$. Xiao et al. investigated the synthesis of conjugates of pentacyclic triterpenes linked to SA at various sites and its effect on antiviral activity [29]. Pentacyclic triterpenes, which can be widely found in Chinese herbal medicine [30], are a class of secondary metabolites [31] with anti-influenza capability [32-34]. In addition to combining with SA, pentacyclic triterpenes can be conjugated with small molecules, such as oligosaccharides $[35,36]$ or L-ascorbic acid [37] —and other macromolecules, such as cyclodextrin [38], methylated cyclodextrin [39], and human serum albumin [40] — to form multivalent copolymers, which considerably improve antiviral activity. These studies are meaningful supplements to heterocyclic compounds related to natural product synthesis, structural analysis, and biological activity research. Heterocyclic compounds not only have biological activity [41,42], but also make outstanding contributions in the field of catalytic reactions [43] and as natural product extractants [44,45]. In our previous work, SGP was hydrolyzed to obtain the glycan portion (SCT-Asn). Surface plasmon resonance (SPR) revealed that SCT-Asn exhibits a moderate affinity to HA, whereas SGP exhibits no affinity to it. Therefore, we modified the SCT-Asn structure and used pentacyclic triterpenes as ligands to synthesize conjugates. We then preliminarily assayed the affinity of conjugates to the HA protein through SPR.

\section{Results and Discussion}

\subsection{Chemistry}

Four pentacyclic triterpenes, namely ursolic acid (UA, ursane type), betulinic acid (BA, lupane type), oleanolic acid (OA, oleanane type), and glycyrrhetinic acid (GA, oleanane type) were selected as ligands (Figure 1). We assembled four oligosaccharide-carrying pentacyclic triterpene conjugates and evaluated their influenza activities by testing their affinity with HA.

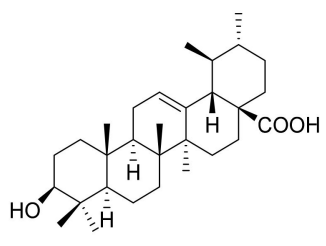

ursolic acid

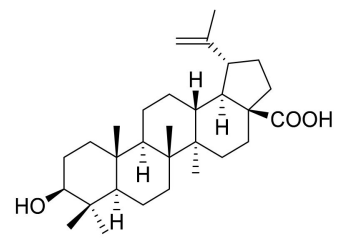

betulinic acid

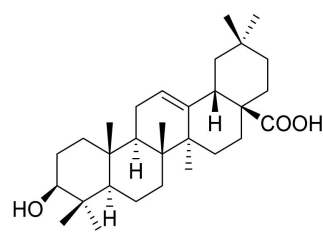

oleanolic acid

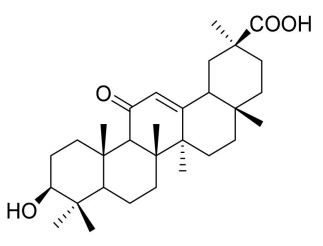

glycyrrhetinic acid

Figure 1. Chemical structures of four parent pentacyclic triterpenes.

Here, $10 \mathrm{~g}$ of SGP was obtained from $20 \mathrm{~kg}$ of egg yolk powder using a method described in the literature [12]. First, alkyne-labeled N-glycan was prepared (Scheme 1). SGP was then thoroughly digested with pronase to remove its peptide portion, leaving asparagine (Asn)-linked N-glycans (SCT-Asn). The process was monitored through high performance liquid chromatography (HPLC) coupled with an ultraviolet detector. The retention time $\left(t_{\mathrm{R}}\right)$ of SCT-Asn was $13.8 \mathrm{~min}$, and it was well separated from the SGP peak $\left(t_{R}=21.7 \mathrm{~min}\right)$ under the same chromatographic conditions. After the digestion was complete, the residue was subjected to size-exclusion chromatography (Sephadex G-50) and lyophilized to obtain SCT-Asn (yield $=73.4 \%$ ). The identity of SCT-Asn was confirmed through electrospray ionization mass spectrometry (ESI-MS) analysis. 


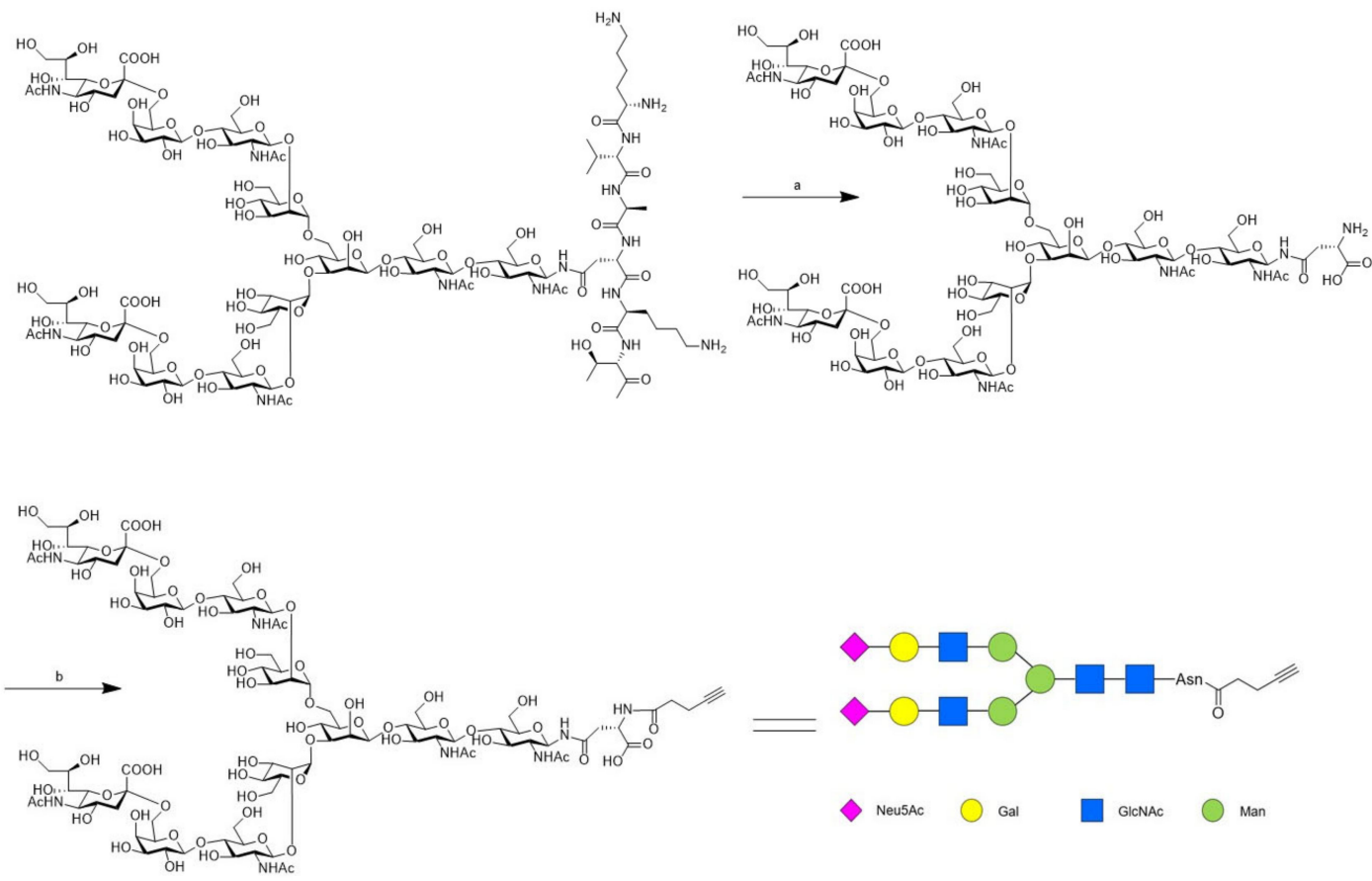

Scheme 1. Synthesis of SCT-Asn-alkyne: (a) pronase, $0.5 \% \mathrm{SDS}, 10 \mathrm{mM} \mathrm{CaCl}, 0.1 \mathrm{M}$ Tris, $\mathrm{pH} 7.5,37^{\circ} \mathrm{C}, 7 \mathrm{~d}$; (b) pent-4-ynoic acid succinimidyl ester, $\mathrm{H}_{2} \mathrm{O} / \mathrm{DMF}(1 / 1 \mathrm{v} / \mathrm{v}), \mathrm{RT}, 12 \mathrm{~h}$.

To prepare SCT-Asn-alkyne, the obtained SCT-Asn was dissolved in a mixed solvent of water and dimethylformamide (DMF; $1 / 1 v / v)$. Next, the $\mathrm{N}$-(4-pentynoyloxy)-succinimide synthesized in the previous step [46] was added, followed by triethylamine. The mixture was incubated at room temperature for $12 \mathrm{~h}$. The residue was subjected to Sephadex G-25 for purification and lyophilized to obtain SCT-Asn-alkyne as a white solid (yield $=56.7 \%$ ). The identity of SCT-Asn-alkyne was confirmed through ESI-MS analysis.

Second, azido-functionalized derivatives of pentacyclic triterpenes (ursolic acid- $\mathrm{N}_{3}$, betulinic acid- $\mathrm{N}_{3}$, oleanolic acid- $\mathrm{N}_{3}$, and glycyrrhetinic acid- $\mathrm{N}_{3}$ ) were synthesized through the esterification of C-28 or C-30 carboxylic acid with the azide group of Bromo-PEG5azide in yields ranging from $67.6 \%$ to $76.6 \%$ (Scheme 2; the structures of pentacyclic triterpene- $\mathrm{N}_{3}$ are available in Supplementary File, Figure S1). The four compounds were confirmed through thin-layer chromatography (TLC), ESI-MS, and nuclear magnetic resonance (NMR).
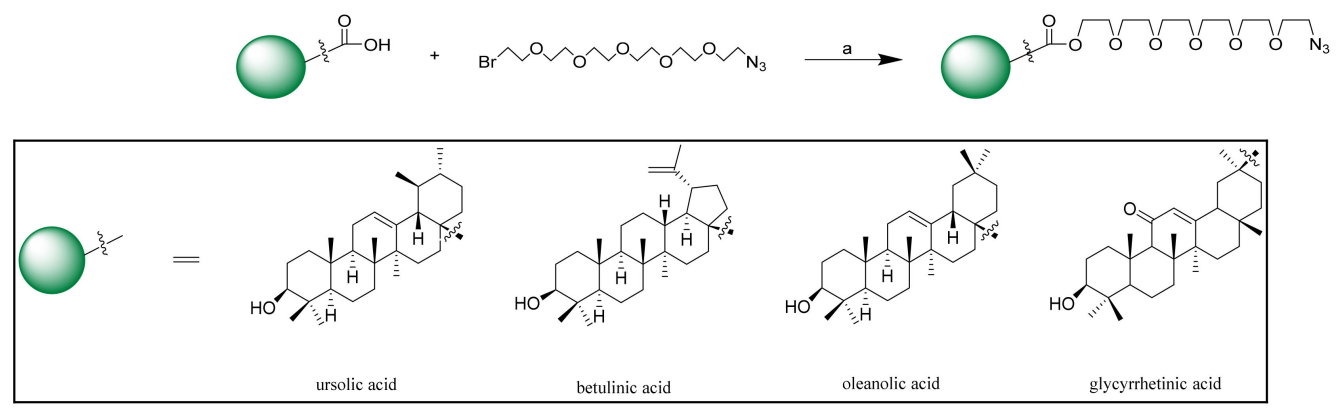

Scheme 2. Synthesis of pentacyclic triterpene- $\mathrm{N}_{3}$ : (a) $\mathrm{K}_{2} \mathrm{CO}_{3}, \mathrm{DMF}, \mathrm{RT}, 18 \mathrm{~h}$.

Finally, the target SCT-Asn-pentacyclic triterpene conjugates were synthesized, as displayed in Scheme 3. The conjugation of SCT-Asn-alkyne and pentacyclic triterpeneazide was achieved through the $\mathrm{Cu}(\mathrm{I})$-catalyzed alkyne-azide cycloaddition reaction (CuAAC) [47]. A solution of the alkyne and azide in THF/ $\mathrm{H}_{2} \mathrm{O}(3 / 2 v / v)$ was stirred with $\mathrm{CuSO}_{4}$, sodium ascorbate, and a copper ligand, tris(benzyltriazolylmethyl)amine (TBTA) [48], at room temperature. The residue was purified through column chromatogra- 
phy to obtain SCT-Asn-UA, SCT-Asn-BA, SCT-Asn-OA, and SCT-Asn-GA in yields ranging from $14.9 \%$ to $29.5 \%$ (the structures of SCT-Asn-pentacyclic triterpene are available in Supplementary File, Figure S2).
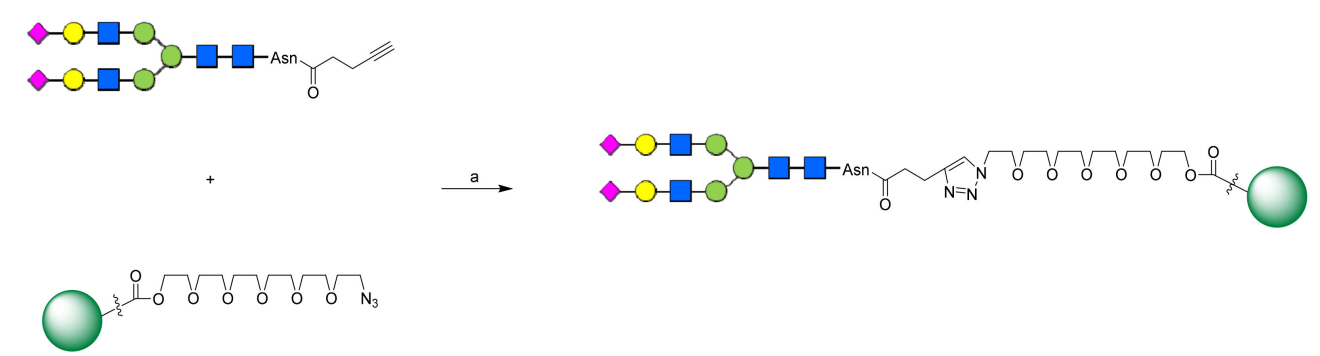

Scheme 3. Synthesis of SCT-Asn-pentacyclic triterpene: (a) TBTA, sodium ascorbate, $\mathrm{CuSO}_{4}$, $\mathrm{THF} / \mathrm{H}_{2} \mathrm{O}(3 / 2 v / v), \mathrm{RT}, 2 \mathrm{~h}$.

\subsection{SPR Assay}

SPR assay showed a certain effectiveness in determining the in vitro anti-influenza virus activity of biomolecules. Many studies have used SPR assay and other tests, such as the time-of-addition experiment, HA inhibition assay, molecular docking analysis, etc., to confirm the target and mechanism [27,35].

Biomolecules with SA residues exhibit certain anti-influenza virus activity. These biomolecules target HA. Therefore, when we investigated the anti-influenza virus activity of the compounds, we first tested its affinity with HA and determined its anti-influenza virus potential. The results could provide guidance for subsequent pharmacological experiments. In this study, we performed SPR assay of four synthesized conjugates with two types of HA, namely H1N1 (A/WSN/1933) and H5N1(A/Hong Kong/483/97), obtained from commercial sources.

The affinity of conjugates for HA was measured though SPR and expressed using the thermodynamic dissociation constant $\left(K_{\mathrm{D}}\right)$. HA was immobilized on the surface of a CM5 chip by using an amine coupling approach. Conjugates at concentrations of $1.562-100 \mu \mathrm{M}$ were injected, and the responses were measured. A Langmuir 1:1 binding model was fit using Biacore evaluation software (GE Healthcare) to determine the binding affinity.

Table 1 shows the results of SPR assay (sensorgrams of SPR assay; see Figures S3 and S4 in Supplementary File). The results revealed that the parent SGP exhibited no affinity with HA, whereas SCT-Asn exhibited enhanced affinity with $K_{\mathrm{D}}$ values of 29.04 and $75.46 \mu \mathrm{M}$ for H1N1 and H5N1, respectively. The polypeptide portion of SGP weakens the interaction between $\mathrm{SA}$ residues and HA.

Table 1. The thermodynamic dissociation constant $K_{\mathrm{D}}(\mu \mathrm{M})$ values of compounds with H1N1(A/WSN/1933) and H5N1(A/Hong Kong/483/97) proteins.

\begin{tabular}{ccc}
\hline Compounds & H1N1(A/WSN/1933) & H5N1(A/Hong Kong/483/97) \\
\hline SGP & ND & ND \\
SCT-Asn & 29.04 & 75.46 \\
UA & 136.70 & ND \\
BA & ND & ND \\
OA & 31.14 & 47.78 \\
GA & 584.00 & $>1000$ \\
SCT-Asn-UA & 289.40 & 852.70 \\
SCT-Asn-BA & 6.89 & 251.60 \\
SCT-Asn-OA & 11.24 & 9.10 \\
SCT-Asn-GA & 16.35 & 13.24 \\
\hline
\end{tabular}

ND: Not detected. SGP: Sialylglycopeptide SCT-Asn: Asparagine (Asn)-linked N-glycans. UA: Ursolic acid BA betulinic acid OA: oleanolic acid GA: glycyrrhetinic acid. 
The results of binding to H1N1 proteins revealed that among the four pentacyclic triterpenes, OA exhibited the best affinity, with a $K_{\mathrm{D}}$ value of $31.14 \mu \mathrm{M}$, whereas BA exhibited no affinity. The affinity of UA and GA was marginally inferior, with $K_{\mathrm{D}}$ values of 136.70 and $584.00 \mu \mathrm{M}$, respectively. For H5N1, OA again exhibited the best affinity, with a $K_{\mathrm{D}}$ value of $47.78 \mu \mathrm{M}$, but the $K_{\mathrm{D}}$ value of GA, UA and BA exhibited no significant affinity.

When the pentacyclic triterpene was linked to SCT-Asn, three conjugates (all except for SCT-Asn-UA) exhibited enhanced affinity with H1N1. Among them, SCT-Asn-BA exhibited the best affinity, with a $K_{\mathrm{D}}$ value of $6.89 \mu \mathrm{M}$ (Figure 2). SCT-Asn-OA and SCT-Asn-GA exhibited the next best $K_{\mathrm{D}}$ values of 11.24 and $16.35 \mu \mathrm{M}$, respectively. The interaction between SA and HA was weak [49], indicating that oligosaccharides and pentacyclic triterpene moieties could enhance this affinity. Additionally, the affinity of the four conjugates to H5N1 was enhanced; the most active conjugate was SCT-Asn-OA, with a $K_{\mathrm{D}}$ value of $9.10 \mu \mathrm{M}$ (Figure 2), followed by SCT-Asn-GA, with a $K_{\mathrm{D}}$ value of $13.24 \mu \mathrm{M}$. Although the affinity of the other two conjugates also improved, their $K_{\mathrm{D}}$ value exceeded $100 \mu \mathrm{M}$. Typically, the affinity of most of the conjugates to HA was higher than that of the parent oligosaccharides and pentacyclic triterpenes. Furthermore, the conjugates exhibited dose-dependent responses, which appeared not to follow specific rules. The fine structures of various pentacyclic triterpenes probably formed various bonds with HA, thus exhibiting various affinities. Notably, the tested conjugates exhibited a binding behavior distinct from that of pentacyclic triterpenes (UA, BA, OA, and GA). The pentacyclic triterpenes exhibited rapid association and dissociation with $\mathrm{HA}$, whereas the conjugates exhibited slow association and dissociation with $\mathrm{HA}$, as evident from the lower association rate constant $\left(K_{\mathrm{a}}\right)$ and dissociation rate constant $\left(K_{\mathrm{d}}\right)$ values. The interaction of conjugates with $\mathrm{HA}$ indicated that the conjugates could form stable complexes with $\mathrm{HA}$, with low $K_{\mathrm{D}}$ values, thus improving antiviral activity against influenza virus. This result is consistent with that of a previous report [38].

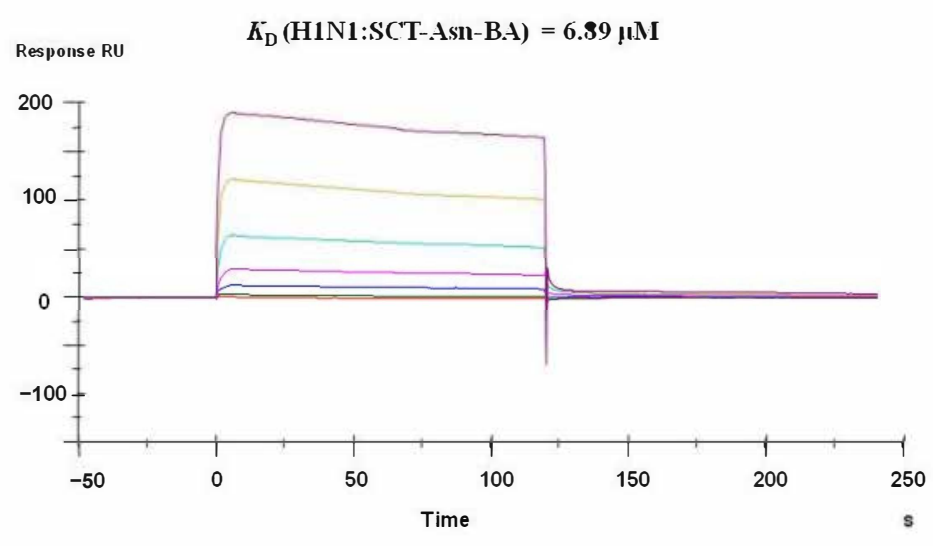

(a)

Figure 2. Cont. 


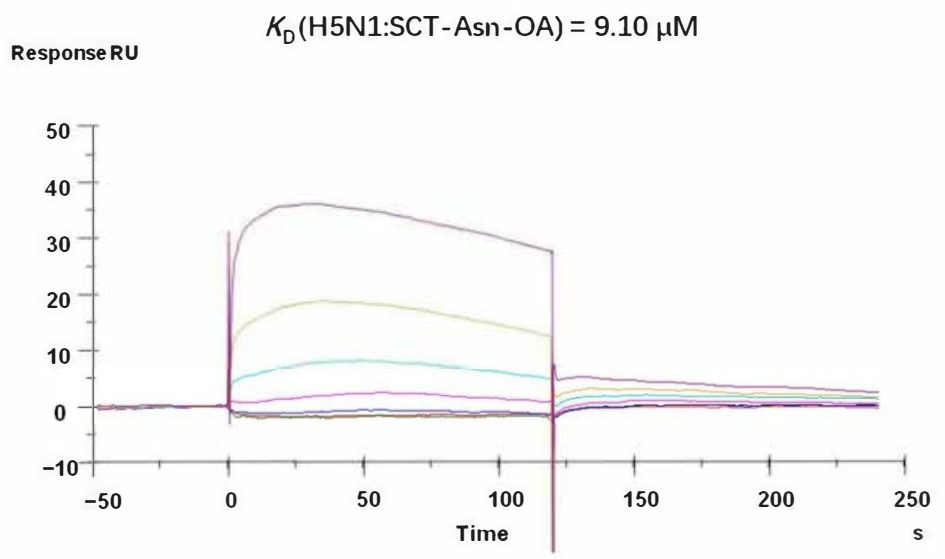

(b)

Figure 2. Surface plasmon resonance (SPR) assay characterization between conjugates and hemagglutinin proteins. (a) SCT-Asn-BA with H1N1(A/WSN/1933) protein; (b) SCT-Asn-OA with H5N1(A/Hong Kong/483/97) protein. Their $K_{D}$ values are labeled in the corresponding curves.

\section{Materials and Methods}

\subsection{Chemistry}

ESI-MS was performed using an LCQ Fleet spectrometer (ThermoFisher Scientific, Waltham, MA, USA) in positive and negative modes. Electron ionization mass spectrometry (EI-MS) was performed with a DFS spectrometer (ThermoFisher Scientific, MA, USA) in positive mode. NMR spectra were recorded on a Bruker AVANCE III HD and AVANCE III 400 spectrometer (Bruker Daltonics, Inc., Billerica, MA, USA) at ambient temperature. ${ }^{1} \mathrm{H}-$ NMR chemical shifts were referenced to the internal standard TMS $\left(\delta_{\mathrm{H}}=0.00\right) .{ }^{13} \mathrm{C}-\mathrm{NMR}$ chemical shifts were referenced to the solvent signal $\left(\delta_{\mathrm{C}}=77.16\right.$ for the central line of $\mathrm{CDCl}_{3}$, $\delta_{C}=49.00$ for the central line of $\mathrm{CD}_{3} \mathrm{OD}$ ). TLC was performed on a precoated silica gel $\mathrm{HSGF}_{254}$ (layer thickness $=0.2 \mathrm{~mm}$; Yantai Jiangyou Silica gel Development Co., Ltd., Yantai, China). Staining with an iodine and $\mathrm{H}_{2} \mathrm{SO}_{4}$ /vanillin solution and subsequent heating were applied for detection. Analytic HPLC was performed on an Agilent 1260 II HPLC instrument (Agilent, Palo Alto, CA, USA) with a XBridge BEH HILIC column (5 $\mu \mathrm{m}$, $4.6 \mathrm{~mm} \times 250 \mathrm{~mm}$, Waters, Milford, MA, USA) at $25^{\circ} \mathrm{C}$. The column was eluted with a linear gradient of $80-64 \% \mathrm{MeCN}$ and $20-36 \% 15 \mathrm{mM} \mathrm{KH}_{2} \mathrm{PO}_{4}$ at $0-10 \mathrm{~min}$, and then eluted with $64 \% \mathrm{MeCN}$ and $36 \% 15 \mathrm{mM} \mathrm{KH}_{2} \mathrm{PO}_{4}$ for $30 \mathrm{~min}$ at a flow rate of $1.2 \mathrm{~mL} / \mathrm{min}$. Sephadex G-25 and Sephadex G-50 (GE Healthcare, Buckinghamshire, UK) were eluted with purified water, and Sephadex LH-20 (GE Healthcare, Buckinghamshire, UK) was eluted with methanol. C18 (Fuji Silysia Chemical Ltd, Aichi, Japan) was activated using methanol and eluted with various concentrations of methanol. Finally, the sample was lyophilized with a lyophilizer (Christ, Alpha 1-2 LD plus, Osterode, Germany).

Pronase was purchased from Roche, and all chemicals were used without further purification. The intermediates and final conjugates were obtained as follows.

\subsubsection{Preparation of SGP}

An extraction method detailed in relevant literature [12] was used for the experiments. First, $20 \mathrm{~kg}$ of egg yolk powder, obtained from commercial suppliers, was defatted twice with $95 \%$ ethanol. The residue was extracted twice with $40 \%$ ethanol. After filtration, the filtrate was concentrated under a reduced pressure at $40{ }^{\circ} \mathrm{C}$, and then $40 \%$ cold ethanol was added to precipitate the proteins, which were then removed through centrifugation. The solution was purified through active carbon/celite column chromatography, and the column was eluted with water, $5 \%$ acetonitrile, $10 \%$ acetonitrile, and $25 \%$ acetonitrile. ESI-MS revealed that SGP was in the $25 \%$ acetonitrile elution portion. Subsequently, the solution was purified through size-exclusion chromatography, and the solutions containing 
SGP were combined and lyophilized to obtain $10.3 \mathrm{~g}$ of white powdery solid $(0.5 \mathrm{mg}$ SGP /g egg yolk powder).

\subsubsection{Preparation of SCT-Asn}

SGP (201.1 mg) was dissolved in a buffer solution (0.1 M Tris, 0.5\% SDS, $10 \mathrm{mM}$ $\mathrm{CaCl}_{2}, \mathrm{pH}$ 7.5). Pronase (202.7 mg) was added, and then the mixture was reacted at $37{ }^{\circ} \mathrm{C}$ for 7 days. Furthermore, $200 \mathrm{mg}$ of pronase was added daily to promote the reaction. The reaction was monitored through HPLC until SGP was converted into SCTAsn. Here, $t_{\mathrm{R}}(\mathrm{SCT}-\mathrm{Asn})=13.8 \mathrm{~min}$ and $t_{\mathrm{R}}(\mathrm{SGP})=21.7 \mathrm{~min}$. After the reaction solution was lyophilized, the residue was dissolved in a small amount of water, then purified using the Sephadex G-50 column and eluted with purified water. The product fraction was collected and lyophilized to obtain a white solid $(120.4 \mathrm{mg}$, yield $=73.4 \%)$. ESI-MS $(\mathrm{m} / \mathrm{z})$ : $1168.7[\mathrm{M}-2 \mathrm{H}]^{2-}, \mathrm{C}_{88} \mathrm{H}_{144} \mathrm{~N}_{8} \mathrm{O}_{64} \cdot{ }^{1} \mathrm{H}-\mathrm{NMR}\left(400 \mathrm{MHz}, \mathrm{D}_{2} \mathrm{O}\right) \delta 5.13$ (s, 1H, H-1 of Man-4), $5.06(\mathrm{~d}, J=9.6 \mathrm{~Hz}, 1 \mathrm{H}, \mathrm{H}-1$ of GlcNAc-1)), 4.94 (s, 1H, H-1 of Man-4'), 4.77 (s, 1H, H-1 of Man-3), 4.61-4.59 (m, 3H, H-1 of GlcNAc-2, GlcNAc-5, GlcNAc-5'), 4.45-4.43 (m, 2H, H-1 of Gal-6, Gal-6'), 4.25 (s, 1H, H-2 of Man-3), 4.19 (s, 1H, H-2 of Man-4), 4.11 (s, 1H, H-2 of Man-4'), 3.09-2.96 (m, 2H, $3-\mathrm{CH}_{2}$ of Asn), 2.67-2.62 (m, 2H, H-3 eq of NeuAc, NeuAc'), 2.08-1.99 (m, 18H, Ac of GlcNAc-1, GlcNAc-2, GlcNAc-5, GlcNAc-5', NeuAc, NeuAc'), $1.82\left(t, J=12.2 \mathrm{~Hz}, 2 \mathrm{H}, \mathrm{H}-3_{\mathrm{ax}}\right.$ of NeuAc, NeuAc' $) .{ }^{13} \mathrm{C}-\mathrm{NMR}\left(151 \mathrm{MHz}, \mathrm{D}_{2} \mathrm{O}\right) \delta 177.7,177.7$, 177.6, 177.5, 176.4, 175.7, 175.3, 107.2, 106.4, 104.1, 103.3, 103.0, 103.0, 102.4, 102.2, 102.1, $99.8,83.5,83.4,83.3,82.5,81.5,80.9,79.2,79.0,77.3,76.5,76.4,76.1,75.6,75.4,75.3,75.0,74.9$, $74.8,74.6,73.6,73.0,72.3,71.2,71.0,70.2,68.7,68.5,66.2,65.5,64.5,63.6,63.1,62.7,62.2,57.8$, $57.5,56.4,54.7,53.7,42.9,37.8,25.3,25.1,24.9$.

\subsubsection{Preparation of SCT-Asn-Alkyne}

First, N-(4-pentynoyloxy)-succinimide was synthesized [41]. 4-Pentynoic acid (392.0 mg, $1 \mathrm{eq})$ and N-hydroxysuccinimide $(466.0 \mathrm{mg}, 1 \mathrm{eq})$ were dissolved in dry THF $(7 \mathrm{~mL})$ and cooled to $0{ }^{\circ} \mathrm{C}$. Next, $\mathrm{N}^{\prime}$-dicyclohexylcarbodiimide $(852.0 \mathrm{mg}, 1 \mathrm{eq})$ dissolved in dry THF $(2 \mathrm{~mL})$ was added dropwise. The mixture was stirred for $1.5 \mathrm{~h}$ at $0{ }^{\circ} \mathrm{C}$, slowly warmed to room temperature, and then stirred for an additional $4 \mathrm{~h}$. The precipitate was filtered, and the solvent was evaporated at a reduced pressure. The residue was dissolved in ethyl acetate, washed with saturated $\mathrm{NaHCO}_{3}$ solution and brine, and dried over $\mathrm{Na}_{2} \mathrm{SO}_{4}$. The solvent was evaporated at a reduced pressure, and the residue dissolved in $\mathrm{MeOH}$ was subject to gel filtration with a Sephadex LH-20 column. The column was eluted with $\mathrm{MeOH}$, and product fractions were combined and concentrated in vacuo to yield pent-4-ynoic acid 1-oxysuccinimidyl ester as a white powder $(545.1 \mathrm{mg}$, yield $=69.9 \%)$. EI-MS $(\mathrm{m} / \mathrm{z})$ : $195[\mathrm{M}]^{+}, \mathrm{C}_{9} \mathrm{H}_{9} \mathrm{NO}_{4} \cdot{ }^{1} \mathrm{H}-\mathrm{NMR}\left(600 \mathrm{MHz}, \mathrm{CD}_{3} \mathrm{OD}\right) \delta 2.87$ (t, J = $\left.7.2 \mathrm{~Hz}, 2 \mathrm{H}, \mathrm{H}-4\right), 2.83$ (s, $4 \mathrm{H}, \mathrm{H}-7), 2.58$ (td, $J=7.2,2.7 \mathrm{~Hz}, 2 \mathrm{H}, \mathrm{H}-3), 2.33$ (t, $J=2.7 \mathrm{~Hz}, 1 \mathrm{H}, \mathrm{H}-1) .{ }^{13} \mathrm{C}-\mathrm{NMR}(101 \mathrm{MHz}$, $\left.\mathrm{CD}_{3} \mathrm{OD}\right) \delta 171.7,168.9,82.2,70.9,31.2,26.5,14.7$.

SCT-Asn (152.4 mg, $1 \mathrm{eq})$ and the succinimidyl ester from the previous step $(64.5 \mathrm{mg}$, $5 \mathrm{eq})$ were dissolved in $4 \mathrm{~mL}$ of solvent $\left(\mathrm{H}_{2} \mathrm{O} / \mathrm{DMF} 1 / 1\right)$. Triethylamine $(27.2 \mu \mathrm{L}, 3 \mathrm{eq})$ was slowly added to the solvent. The mixture was stirred overnight, and the residue was subjected to gel filtration with a Sephadex G-25 column. The column was eluted with $\mathrm{H}_{2} \mathrm{O}$, and product fractions were combined and lyophilized to yield SCT-Asn-alkyne as a white solid $\left(89.0 \mathrm{mg}\right.$, yield = 56.7\%). ESI-MS $(\mathrm{m} / \mathrm{z}): 1209.0[\mathrm{M}-2 \mathrm{H}]^{2-}, \mathrm{C}_{93} \mathrm{H}_{148} \mathrm{~N}_{8} \mathrm{O}_{65} \cdot{ }^{1} \mathrm{H}-\mathrm{NMR}$ $\left(400 \mathrm{MHz}, \mathrm{D}_{2} \mathrm{O}\right) \delta 5.13$ (s, 1H, H-1 of Man-4), 5.04 (d, $J=9.6 \mathrm{~Hz}, 1 \mathrm{H}, \mathrm{H}-1$ of GlcNAc-1), 4.94 (s, 1H, H-1 of Man-4'), 4.77 (s, 1H, H-1 of Man-3), 4.61-4.59 (m, 3H, H-1 of GlcNAc-2, GlcNAc-5, GlcNAc-5') , 4.45-4.43 (m, 2 H, H-1 of Gal-6, Gal-6'), 4.25 (s, 1H, H-2 of Man-3), 4.19 (s, 1H, H-2 of Man-4), 4.11 (s, 1H, H-2 of Man-4'), 2.92-2.80 (m, 2H, $\beta-\mathrm{CH}_{2}$ of Asn), 2.67-2.62 (m, 2H, H-3 eq of NeuAc, NeuAc'), 2.49-2.48 (m, 4H, $\mathrm{CH}_{2} \mathrm{CH}_{2}$-alkyne), $2.36(\mathrm{t}$, $J=2.3 \mathrm{~Hz}, 1 \mathrm{H}, \mathrm{H}$ of alkyne), 2.07-1.99 (m, 18H, Ac of GlcNAc-1, GlcNAc-2, GlcNAc-5, GlcNAc-5', NeuAc, NeuAc' $), 1.82$ ( $\mathrm{t}, J=12.2 \mathrm{~Hz}, 2 \mathrm{H}, \mathrm{H}-3 \mathrm{ax}$ of NeuAc, NeuAc'). ${ }^{13} \mathrm{C}-\mathrm{NMR}$ $\left(151 \mathrm{MHz}, \mathrm{D}_{2} \mathrm{O}\right) \delta 177.8,177.7,177.6,177.4,177.0,175.6,174.5,166.0,165.8,120.3,118.3$, 106.6, 104.3, 103.4, 102.5, 102.2, 101.9, 99.9, 98.2, 86.2, 83.6, 83.4, 82.6, 81.6, 81.2, 79.4, 79.2, 
$78.3,77.4,76.5,75.8,75.7,75.5,75.4,75.0,75.0,74.0,73.6,73.4,73.2,73.1,72.4,71.4,71.3,71.2$, $70.5,70.3,69.7,68.7,66.3,66.1,65.9,64.7,64.6,64.0,63.2,62.9,62.8,57.9,57.6,56.8,55.0,54.7$, $51.9,42.1,41.8,39.8,37.0,25.4,25.4,25.3,25.2,25.1,25.0,25.0,17.3$.

\subsubsection{General Procedure for Preparing Pentacyclic Triterpenes with the Azide Group}

$\mathrm{K}_{2} \mathrm{CO}_{3}(2 \mathrm{eq})$ was added to a solution of pentacyclic triterpenes (1.1 eq) and BromoPEG5-azide (1 eq) in DMF. The reaction mixture was stirred at room temperature for $18-24 \mathrm{~h}$ and concentrated in vacuo. The residue was diluted with dichloromethane or ethyl acetate, and the extract was washed successively with saturated $\mathrm{NaHCO}_{3}$ and brine before being dried with $\mathrm{Na}_{2} \mathrm{SO}_{4}$, filtered, and concentrated in vacuo. The residue was purified through gel filtration with a Sephadex LH-20 column, and the column was eluted with $\mathrm{MeOH}$; product fractions were combined and concentrated in vacuo.

$\mathrm{UA}-\mathrm{N}_{3}$

UA- $\mathrm{N}_{3}$ was prepared from ursolic acid (201.1 mg, $1.1 \mathrm{eq)}$ ) and Bromo-PEG5-azide (147.9 mg, 1 eq) according to the general procedure. The residue was purified to yield UA$\mathrm{N}_{3}$ as a colorless oil $(201.5 \mathrm{mg}$, yield $=67.6 \%)$. ESI-MS $(\mathrm{m} / \mathrm{z}): 747.2\left[\mathrm{M}+\mathrm{H}^{+}, \mathrm{C}_{42} \mathrm{H}_{71} \mathrm{~N}_{3} \mathrm{O}_{8}\right.$. ${ }^{1} \mathrm{H}-\mathrm{NMR}\left(600 \mathrm{MHz}, \mathrm{CDCl}_{3}\right) \delta 5.24(\mathrm{t}, J=3.7 \mathrm{~Hz}, 1 \mathrm{H}, \mathrm{CH}-12), 4.15(\mathrm{t}, J=5.1 \mathrm{~Hz}, 2 \mathrm{H}), 3.69-3.63$ $(\mathrm{m}, 22 \mathrm{H}), 3.39(\mathrm{t}, J=5.1 \mathrm{~Hz}, 2 \mathrm{H}), 3.22(\mathrm{dd}, J=11.3,4.7 \mathrm{~Hz}, 1 \mathrm{H}, \mathrm{CH}-3), 2.24(\mathrm{~d}, J=11.3 \mathrm{~Hz}$, $\left.1 \mathrm{H}, \mathrm{CH}-18), 2.00\left(\mathrm{td}, J=13.5,4.5 \mathrm{~Hz}, 1 \mathrm{H}, \mathrm{CH}_{2(\mathrm{H} \beta}\right)-15\right), 1.91-1.89(\mathrm{~m}, 2 \mathrm{H}), 1.81-1.76(\mathrm{~m}, 1 \mathrm{H})$, $1.74(\mathrm{~s}, 2 \mathrm{H}), 1.70-1.65(\mathrm{~m}, 3 \mathrm{H}), 1.63-1.56(\mathrm{~m}, 4 \mathrm{H}), 1.54-1.46(\mathrm{~m}, 5 \mathrm{H}), 1.36-1.26(\mathrm{~m}, 6 \mathrm{H}), 1.08$ (s, 3H, $\left.\mathrm{CH}_{3}-27\right), 1.06-1.05$ (m, 1H, CH-20), 0.99 (s, 3H, $\left.\mathrm{CH}_{3}-23\right), 0.95(\mathrm{~d}, J=6.3 \mathrm{~Hz}, 3 \mathrm{H}$, $\left.\mathrm{CH}_{3}-29\right), 0.92$ (s, 3H, $\left.\mathrm{CH}_{3}-26\right), 0.86\left(\mathrm{~d}, J=6.5 \mathrm{~Hz}, 3 \mathrm{H}, \mathrm{CH}_{3}-30\right), 0.78\left(\mathrm{~s}, 3 \mathrm{H}, \mathrm{CH}_{3}-24\right), 0.75$ (s, $\left.3 \mathrm{H}, \mathrm{CH}_{3}-25\right), 0.72(\mathrm{~d}, \mathrm{~J}=11.8 \mathrm{~Hz}, 1 \mathrm{H}, \mathrm{CH}-5) .{ }^{13} \mathrm{C}-\mathrm{NMR}\left(151 \mathrm{MHz}, \mathrm{CDCl}_{3}\right) \delta 177.6,138.2$, $125.7,79.2,70.8,70.8,70.8,70.8,70.7,70.7,70.7,70.2,69.3,63.4,55.3,53.0,50.8,48.2,47.7$, $42.2,39.7,39.2,39.0,38.9,38.8,37.1,36.7,33.2,30.8,28.3,28.1,27.4,24.3,23.7,23.4,21.3,18.5$, $17.2,17.1,15.8,15.6$.

$\mathrm{OA}-\mathrm{N}_{3}$

OA-N $\mathrm{N}_{3}$ was prepared from oleanolic acid $(50.3 \mathrm{mg}, 1.1 \mathrm{eq})$ and Bromo-PEG5-azide ( $37.4 \mathrm{mg}, 1 \mathrm{eq}$ ) according to the general procedure. The residue was purified to yield $\mathrm{OA}-\mathrm{N}_{3}$ as a colorless oil $(51.8 \mathrm{mg}$, yield $=68.7 \%)$. ESI-MS $(\mathrm{m} / \mathrm{z})$ : $746.5[\mathrm{M}+\mathrm{H}]^{+}, \mathrm{C}_{42} \mathrm{H}_{71} \mathrm{~N}_{3} \mathrm{O}_{8}$. ${ }^{1} \mathrm{H}-\mathrm{NMR}\left(600 \mathrm{MHz}, \mathrm{CDCl}_{3}\right) \delta 5.28(\mathrm{t}, J=3.7 \mathrm{~Hz}, 1 \mathrm{H}, \mathrm{CH}-12), 4.22-4.13(\mathrm{~m}, 2 \mathrm{H}), 3.68-3.64$ $(\mathrm{m}, 22 \mathrm{H}), 3.39(\mathrm{t}, J=5.1 \mathrm{~Hz}, 2 \mathrm{H}), 3.22-3.19(\mathrm{~m}, 1 \mathrm{H}, \mathrm{CH}-3), 2.86(\mathrm{dd}, J=13.9,4.6 \mathrm{~Hz}, 1 \mathrm{H}$, CH-18), 1.99-1.94 (m, 2H), 1.89-1.86 (m, 2H, $\left.\mathrm{CH}_{2}-22\right), 1.72-1.69(\mathrm{~m}, 1 \mathrm{H}), 1.67-1.59(\mathrm{~m}, 7 \mathrm{H})$, 1.55-1.52 (m, 4H), 1.47-1.25 (m, 6H), 1.20-1.15 (m, 3H), $1.13\left(\mathrm{~s}, 3 \mathrm{H}, \mathrm{CH}_{3}-27\right), 1.06(\mathrm{~m}, 2 \mathrm{H}$, $\left.\mathrm{CH}_{2}-1\right), 0.98$ (s, 3H, $\left.\mathrm{CH}_{3}-25\right), 0.92\left(\mathrm{~s}, 3 \mathrm{H}, \mathrm{CH}_{3}-23\right), 0.90$ (s,3H, $\left.\mathrm{CH}_{3}-30\right), 0.90$ (s, 3H, $\left.\mathrm{CH}_{3}-29\right)$, $0.78\left(\mathrm{~s}, 3 \mathrm{H}, \mathrm{CH}_{3}-26\right), 0.73\left(\mathrm{~s}, 3 \mathrm{H}, \mathrm{CH}_{3}-24\right), 0.72(\mathrm{~m}, 1 \mathrm{H}, \mathrm{CH}-5) .{ }^{13} \mathrm{C}-\mathrm{NMR}\left(101 \mathrm{MHz}, \mathrm{CDCl}_{3}\right)$ $\delta$ 177.6, 143.7, 122.4, 78.9, 70.7, 70.6, 70.6, 70.6, 70.5, 70.5, 70.5, 70.0, 69.1, 63.3, 55.2, 50.6, 47.6, $46.6,45.8,41.7,41.2,39.3,38.7,38.4,37.0,33.8,33.1,32.7,32.3,30.7,28.1,27.6,27.2,25.8,23.6$, $23.4,22.9,18.3,17.0,15.6,15.3$.

\section{$\mathrm{BA}-\mathrm{N}_{3}$}

BA-N $\mathrm{N}_{3}$ was prepared from betulinic acid $(50.3 \mathrm{mg}, 1.1 \mathrm{eq})$ and Bromo-PEG5-azide ( $40.9 \mathrm{mg}, 1 \mathrm{eq}$ ) according to the general procedure. The residue was purified to yield $\mathrm{BA}-\mathrm{N}_{3}$ as a colorless oil $(56.8 \mathrm{mg}$, yield $=69.0 \%)$. ESI-MS $(\mathrm{m} / \mathrm{z})$ : $746.3[\mathrm{M}+\mathrm{H}]^{+}, \mathrm{C}_{42} \mathrm{H}_{71} \mathrm{~N}_{3} \mathrm{O}_{8}$. ${ }^{1} \mathrm{H}-\mathrm{NMR}\left(400 \mathrm{MHz}, \mathrm{CD}_{3} \mathrm{OD}\right) \delta 4.72(\mathrm{~d}, J=2.3 \mathrm{~Hz}, 1 \mathrm{H}, \mathrm{Ha}-29), 4.60(\mathrm{~d}, J=2.4 \mathrm{~Hz}, 1 \mathrm{H}$, $\mathrm{Hb}-29), 4.28-4.17(\mathrm{~m}, 2 \mathrm{H}), 3.71-3.63(\mathrm{~m}, 22 \mathrm{H}), 3.37(\mathrm{t}, J=4.9 \mathrm{~Hz}, 2 \mathrm{H}), 3.34(\mathrm{~s}, 1 \mathrm{H}), 3.12(\mathrm{dd}$, $J=11.1,5.1 \mathrm{~Hz}, 1 \mathrm{H}, \mathrm{CH}-3), 3.02(\mathrm{td}, J=10.5,4.5 \mathrm{~Hz}, 1 \mathrm{H}, \mathrm{H}-19), 2.29-2.22(\mathrm{~m}, 2 \mathrm{H}), 1.94-1.87$ $\left(\mathrm{m}, 2 \mathrm{H}, \mathrm{CH}_{2}-16\right), 1.70\left(\mathrm{~s}, 3 \mathrm{H}, \mathrm{CH}_{3}-30\right), 1.65-1.52(\mathrm{~m}, 4 \mathrm{H}), 1.49-1.35(\mathrm{~m}, 9 \mathrm{H}), 1.32-1.23(\mathrm{~m}$, $2 \mathrm{H}), 1.19-1.04(\mathrm{~m}, 2 \mathrm{H}), 1.00\left(\mathrm{~s}, 3 \mathrm{H}, \mathrm{CH}_{3}-26\right), 0.95\left(\mathrm{~s}, 6 \mathrm{H}, \mathrm{CH}_{3}-23,24\right), 0.86\left(\mathrm{~s}, 3 \mathrm{H}, \mathrm{CH}_{3}-25\right)$, 0.75 (s, 3H, $\left.\mathrm{CH}_{3}-27\right), 0.72-0.69(\mathrm{~m}, 1 \mathrm{H}) .{ }^{13} \mathrm{C}-\mathrm{NMR}\left(101 \mathrm{MHz}, \mathrm{CD}_{3} \mathrm{OD}\right) \delta 177.4,151.8,110.4$, 79.6, 71.6, 71.6, 71.6, 71.6, 71.5, 71.2, 70.3, 64.2, 57.9, 56.8, 51.9, 51.8, 50.6, 49.4, 48.5, 43.6, 42.0, 
$40.1,40.0,39.6,38.3,38.0,35.6,33.1,31.7,30.8,28.7,28.0,26.8,22.1,19.6,19.5,16.8,16.8$, $16.2,15.2$.

$\mathrm{GA}-\mathrm{N}_{3}$

GA-N 3 was prepared from glycyrrhetinic acid $(52.2 \mathrm{mg}, 1.1 \mathrm{eq})$ and Bromo-PEG5azide (37.1 mg, $1 \mathrm{eq}$ ) according to the general procedure. The residue was purified to yield GA-N $\mathrm{N}_{3}$ as a colorless oil $(58.2 \mathrm{mg}$, yield $=76.6 \%)$. ESI-MS $(\mathrm{m} / \mathrm{z}): 760.8[\mathrm{M}+\mathrm{H}]^{+}$, $\mathrm{C}_{42} \mathrm{H}_{69} \mathrm{~N}_{3} \mathrm{O}_{9} .{ }^{1} \mathrm{H}-\mathrm{NMR}\left(400 \mathrm{MHz}, \mathrm{CD}_{3} \mathrm{OD}\right) \delta 5.62$ (s, 1H, CH-12), 4.38-4.18 (m, 2H), 4.10 (q, $J=7.1 \mathrm{~Hz}, 1 \mathrm{H}), 3.74-3.62(\mathrm{~m}, 22 \mathrm{H}), 3.41-3.39(\mathrm{~m}, 2 \mathrm{H}), 3.17(\mathrm{~m}, 1 \mathrm{H}, \mathrm{CH}-3), 2.73(\mathrm{dt}, J=13.4$, $3.6 \mathrm{~Hz}, 1 \mathrm{H}), 2.44(\mathrm{~s}, 1 \mathrm{H}), 2.21-2.11(\mathrm{~m}, 2 \mathrm{H}), 1.78-1.46(\mathrm{~m}, 8 \mathrm{H}), 1.42\left(\mathrm{~s}, 3 \mathrm{H}, \mathrm{CH}_{3}-27\right), 1.28-1.22$ (m, 3H), 1.16 (s, 3H, $\left.\mathrm{CH}_{3}-29\right), 1.14\left(\mathrm{~s}, 6 \mathrm{H}, \mathrm{CH}_{3}-26, \mathrm{CH}_{3}-25\right), 1.06-1.01(\mathrm{~m}, 2 \mathrm{H}), 0.99$ (s, 3H, $\left.\mathrm{CH}_{3}-23\right), 0.83$ (s, 3H, $\left.\mathrm{CH}_{3}-24\right), 0.80$ (s, 3H, $\left.\mathrm{CH}_{3}-28\right) .{ }^{13} \mathrm{C}-\mathrm{NMR}\left(101 \mathrm{MHz}, \mathrm{CD}_{3} \mathrm{OD}\right) \delta 202.3$, 178.1, 172.5, 129.0, 79.3, 71.4, 71.4, 71.4, 71.3, 71.0, 70.3, 64.6, 63.1, 61.5, 56.1, 51.8, 49.8, 49.7, $46.7,45.3,44.5,42.3,40.3,40.2,38.9,38.3,33.8,32.9,32.0,29.2,28.7,28.6,27.8,27.6,27.4,23.9$, $20.9,19.3,18.6,17.0,16.4,14.5$.

\subsubsection{General Procedure for Preparing SCT-Asn-Pentacyclic Triterpene Conjugates}

In this procedure, TBTA, $0.1 \mathrm{M} \mathrm{CuSO}_{4}$ and $0.1 \mathrm{M}$ sodium ascorbate was added to a solution of SCT-Asn-alkyne and pentacyclic triterpenoids in a solvent of THF $/ \mathrm{H}_{2} \mathrm{O}(3 / 2$ $v / v)$. The solution was stirred at room temperature for $5 \mathrm{~h}$. The solvent was concentrated, then the residue was redissolved in $\mathrm{MeOH}$ and subjected to gel filtration with a Sephadex LH-20 column. The column was eluted with $\mathrm{MeOH}$, and product fractions were combined. The residue was purified using a $\mathrm{C} 18$ column and eluted with $\mathrm{H}_{2} \mathrm{O}, 10 \% \mathrm{MeOH}, 20 \%$ $\mathrm{MeOH}, 30 \% \mathrm{MeOH}, 35 \% \mathrm{MeOH}, 40 \% \mathrm{MeOH}, 45 \% \mathrm{MeOH}, 50 \% \mathrm{MeOH}, 55 \% \mathrm{MeOH}, 60 \%$ $\mathrm{MeOH}, 65 \% \mathrm{MeOH}, 70 \% \mathrm{MeOH}, 80 \% \mathrm{MeOH}, 90 \% \mathrm{MeOH}$, and $100 \% \mathrm{MeOH}$, and the product fractions were combined and concentrated in vacuo and then lyophilized.

\section{SCT-Asn-UA}

SCT-Asn-UA was prepared from SCT-Asn-alkyne (50.2 mg, 1 eq) and UA-N 3 (63.6 mg, $4 \mathrm{eq})$ according to the general procedure. SCT-Asn-UA was synthesized as a white solid $(19.4 \mathrm{mg}$, yield $=29.5 \%$ ). ESI-MS (negative mode, $\mathrm{m} / \mathrm{z}): 1581.5[\mathrm{M}-2 \mathrm{H}]^{2-}, 1054.9$ $[\mathrm{M}-3 \mathrm{H}]^{3-}$; HR-ESI-MS (positive mode, $\left.\mathrm{m} / \mathrm{z}\right) 1582.1941[\mathrm{M}+2 \mathrm{H}]^{2+}$ (calcd 1582.1954); $\mathrm{C}_{135} \mathrm{H}_{219} \mathrm{~N}_{11} \mathrm{O}_{73} \cdot{ }^{1} \mathrm{H}-\mathrm{NMR}\left(400 \mathrm{MHz}, \mathrm{CD}_{3} \mathrm{OD}\right) \delta 5.24$ (m, 1H, CH-12), 5.12 (s, 1H, H-1 of Man-4), 4.34-4.32 (m, 2H, H-1 of Gal-6,Gal-6'), 4.18 (s, 1H, H-2 of Man-4), 3.15 (dd, J = 11.0, $4.6 \mathrm{~Hz}, 1 \mathrm{H}, \mathrm{CH}-3), 3.03-2.97$ (m, 2H, $\beta-\mathrm{CH}_{2}$ of Asn), 2.78-2.75 (m, 2H, H-3 eq of NeuAc, NeuAc'), 2.24 (d, J = 11.4 Hz, 1H, CH-18), 2.10-1.84 (m, 18H, NAc of GlcNAc-1, GlcNAc-2, GlcNAc-5, GlcNAc-5', NeuAc, NeuAc'), 1.11 (s, 3H, CH $3-27), 0.97-0.95$ (m, 9H, $\mathrm{CH}_{3}-23$, $\left.\mathrm{CH}_{3}-29, \mathrm{CH}_{3}-26\right), 0.88\left(\mathrm{~d}, \mathrm{~J}=6.4 \mathrm{~Hz}, 3 \mathrm{H}, \mathrm{CH}_{3}-30\right), 0.78-0.77\left(2 \mathrm{~s}, 6 \mathrm{H}, \mathrm{CH}_{3}-24, \mathrm{CH}_{3}-25\right)$.

\section{SCT-Asn-OA}

SCT-Asn-OA was prepared from SCT-Asn-alkyne $(67.6 \mathrm{mg}, 1 \mathrm{eq})$ and OA-N 3 (51.8 mg, $2 \mathrm{eq})$ according to the general procedure. SCT-Asn-OA was synthesized as a white solid $(13.2 \mathrm{mg}$, yield $=14.9 \%) . \mathrm{C}_{135} \mathrm{H}_{219} \mathrm{~N}_{11} \mathrm{O}_{73}$, ESI-MS (negative mode, $\mathrm{m} / \mathrm{z}$ ): 1581.4 [M $2 \mathrm{H}]^{2-}, 1054.3[\mathrm{M}-3 \mathrm{H}]^{3-} ; \mathrm{HR}-\mathrm{ESI}-\mathrm{MS}$ (positive mode, $\left.\mathrm{m} / z\right) 1582.1963[\mathrm{M}+2 \mathrm{H}]^{2+}$ (calcd 1582.1954,); ${ }^{1} \mathrm{H}-\mathrm{NMR}\left(600 \mathrm{MHz}, \mathrm{CD}_{3} \mathrm{OD}\right) \delta 5.25$ (m, 1H, CH-12), 5.12 (s, 1H, H-1 of Man-4), 4.34-4.33 (m, 2H, H-1 of Gal-6,Gal-6'), 4.18 (s, 1H, H-2 of Man-4), 3.64-3.59 (m, 22H), 3.00 (m, 2H, $3-\mathrm{CH}_{2}$ of Asn), 2.89-2.87 (m, 1H, CH-18), 2.60 (m, 2H, H-3 eq of NeuAc, NeuAc'), 2.05-1.89 (m, 18H, NAc of GlcNAc-1, GlcNAc-2, GlcNAc-5, GlcNAc-5', NeuAc, NeuAc'), 1.15 (s, 3H, $\left.\mathrm{CH}_{3}-27\right), 0.97$ (s, 3H, $\left.\mathrm{CH}_{3}-25\right), 0.94-0.89\left(\mathrm{~m}, 9 \mathrm{H}, \mathrm{CH}_{3}-23, \mathrm{CH}_{3}-30, \mathrm{CH}_{3}-29\right)$, $0.77-0.76\left(2 \mathrm{~s}, 6 \mathrm{H}, \mathrm{CH}_{3}-26, \mathrm{CH}_{3}-24\right)$.

\section{SCT-Asn-BA}

SCT-Asn-BA was prepared from SCT-Asn-alkyne $(68.0 \mathrm{mg}, 1 \mathrm{eq})$ and BA-N 3 (56.8 mg, $2.7 \mathrm{eq}$ ) according to the general procedure. SCT-Asn-BA was synthesized as a white solid 
(21.2 mg, 23.8\%). $\mathrm{C}_{135} \mathrm{H}_{219} \mathrm{~N}_{11} \mathrm{O}_{73}$, ESI-MS (negative mode, $\left.m / z\right): 1581.3[\mathrm{M}-2 \mathrm{H}]^{2-}, 1054.1$ $[\mathrm{M}-3 \mathrm{H}]^{3} ; \mathrm{HR}-\mathrm{HSI}-\mathrm{MS}$ (positive mode, $\left.\mathrm{m} / \mathrm{z}\right) 1582.1974[\mathrm{M}+2 \mathrm{H}]^{2+}(\mathrm{calcd} 1582.1954) ;{ }^{1} \mathrm{H}-\mathrm{NMR}$ (600 MHz, CD 3 OD) $\delta 5.13$ (s, 1H, H-1 of Man-4), 4.34-4.33 (m, 2H, H-1 of Gal-6, Gal-6'), 3.12 (dd, $J=11.5,4.7 \mathrm{~Hz}, 1 \mathrm{H}, \mathrm{CH}-3), 2.78-2.76\left(\mathrm{~m}, 2 \mathrm{H}, \beta-\mathrm{CH}_{2}\right.$ of Asn), 2.61-2.58 (m, 2H, H-3 of NeuAc, NeuAc'), 2.05-1.96 (m, 18H, NAc of GlcNAc-1, GlcNAc-2, GlcNAc-5, GlcNAc-5', NeuAc, NeuAc'), 1.69 (s, 3H, CH $3-30), 1.00$ (s, 3H, $\left.\mathrm{CH}_{3}-26\right), 0.94$ (s, 6H, $\left.\mathrm{CH}_{3}-23,24\right), 0.85$ (s, $\left.3 \mathrm{H}, \mathrm{CH}_{3}-25\right), 0.75$ (s, 3H, $\left.\mathrm{CH}_{3}-27\right)$.

\section{SCT-Asn-GA}

SCT-Asn-GA was prepared from SCT-Asn-alkyne (50.4 mg, 1 eq) and GA-N 3 (58.2 mg, $3.7 \mathrm{eq})$ according to the general procedure. SCT-Asn-GA was synthesized as a white solid (11.6 mg, 17.5\%). $\mathrm{C}_{135} \mathrm{H}_{217} \mathrm{~N}_{11} \mathrm{O}_{74}$, ESI-MS (negative mode, $\left.m / z\right): 1588.2[\mathrm{M}-2 \mathrm{H}]^{2-}, 1058.5$ $[\mathrm{M}-3 \mathrm{H}]^{3-}$; HR-ESI-MS (positive mode, $\left.m / z\right) 1589.1852[\mathrm{M}+2 \mathrm{H}]^{2+}($ calcd 1589.1850$) ;{ }^{1} \mathrm{H}-$ NMR (600 MHz, CD 3 OD) $\delta 5.61$ (s, 1H, CH-12), 5.13 (s, 1H, H-1 of Man-4), 4.34-4.33 (m, 2H, H-1 of Gal-6,Gal-6'), 3.00 (m, 2H, $\beta-\mathrm{CH}_{2}$ of Asn), 2.60 (m, 2H, H-3 eq of NeuAc, NeuAc'), 1.42 (s, 3H, $\left.\mathrm{CH}_{3}-27\right), 1.16$ (s, 3H, $\left.\mathrm{CH}_{3}-29\right), 1.14$ (s, 6H, $\left.\mathrm{CH}_{3}-26,25\right), 0.99$ (s, 3H, $\left.\mathrm{CH}_{3}-23\right), 0.83$ (s, 3H, $\left.\mathrm{CH}_{3}-24\right), 0.80$ (s, 3H, $\left.\mathrm{CH}_{3}-28\right)$.

\subsection{SPR Assay}

Biacore T200 instruments (GE Healthcare) were used to evaluate the binding affinity of compounds with H1N1 (A/WSN/1933) and H5N1 (A/Hong Kong/483/97), purchased from Sino Biological Inc. (Beijing, China) through SPR, as previously described [50]. In brief, HA protein was immobilized on the surface of a CM5 chip by using the amine coupling approach at a flow rate of $10 \mu \mathrm{L} / \mathrm{min}$ in $10 \mathrm{mM}$ sodium acetate buffer ( $\mathrm{pH}$ 5.0). The sensor surface was activated with a 7 min injection of a mixture of $50 \mathrm{mM}$ N-hydroxysuccinimide (NHS) and $200 \mathrm{mM}$ 1-ethyl-3-(3-dimethylaminopropyl) carbodiimide (EDC). Next, $25 \mu \mathrm{g} / \mathrm{mL}$ HA protein was injected to reach the target level of approximately 15,000 RU for $420 \mathrm{~s}$, and the surface was blocked with $1 \mathrm{M}$ ethanolamine, $\mathrm{pH}$ 8.5. The coupling amount of H1N1 was $15886.4 \mathrm{RU}$, and the coupling amount of H5N1 was 7203.8 RU. Series concentrations of compounds were injected into the flow system and analyzed for $90 \mathrm{~s}$, and dissociation occurred for $90 \mathrm{~s}$. All binding analyses were performed in phosphate-buffered saline (PBS) with $0.05 \%(v / v)$ Tween 20 and 5\% DMSO, pH 7.4, at $25^{\circ} \mathrm{C}$. Prior to analysis, double reference subtraction and solvent correction were performed to eliminate bulk refractive index changes, injection noise, and data drift. A Langmuir 1:1 binding model was fit using Biacore evaluation software (GE Healthcare) to determine the binding affinity.

\section{Conclusions}

A total of four SCT-Asn-pentacyclic triterpene conjugates were synthesized, and their anti-influenza activity was preliminarily investigated through SPR assays. The most promising result was observed for SCT-Asn-BA, which bonded to H1N1 with a $K_{\mathrm{D}}$ value of $6.89 \mu \mathrm{M}$. Furthermore, SCT-Asn-OA bonded to H5N1 with a $K_{\mathrm{D}}$ value of $9.10 \mu \mathrm{M}$, thus disrupting the interaction of HA with SA. Future studies should analyze the anti-influenza virus activity of these conjugates at the cellular level. Compared with the parent SCTAsn and the pentacyclic triterpenes, the conjugate exhibited an increased affinity, which indicated that the influence of the nonsialic acid part on the structure should be considered. Generally, molecules with high affinity to HA also have the potential to inhibit influenza viruses by disrupting the attachment of viruses to host cells. This study may provide guidance for the design of anti-influenza compounds, that is, to synthesize two low-activity compounds into a conjugate. 
Supplementary Materials: The following are available online. Figure S1: Chemical structures of four pentacyclic triterpene-N3. Figure S2: Chemical structures of four SCT-Asn-pentacyclic triterpene. Figure S3: SPR assay to determine the affinity of compounds to H1N1 (A/WSN/1933) protein immobilized on a CM5 sensor chip. Figure S4: SPR assay to determine the affinity of compounds to H5N1 (A/Hong Kong/483/97) protein immobilized on a CM5 sensor chip. ${ }^{1} \mathrm{H}-,{ }^{13} \mathrm{C}-\mathrm{NMR}$, and MS spectra of intermediate and final products. High resolution mass spectra of four conjugates.

Author Contributions: F.G. and Y.L. conceived and designed the main ideas of this study; X.W. performed the isolation of SGP; M.L. performed the synthesis experiments and wrote the original draft; All authors have read and agreed to the published version of the manuscript.

Funding: This research received no external funding.

Data Availability Statement: The data presented in this study are available within the article and in Supplementary Materials.

Acknowledgments: Thanks to Shanghai Jiao Tong University for providing SPR testing services.

Conflicts of Interest: The authors declare no conflict of interest.

Sample Availability: Samples of the compounds are not available from the authors.

\section{References}

1. World Health Organization. Influenza (Seasonal). Available online: https://www.who.int/news-room/fact-sheets/detail/ influenza-(seasonal) (accessed on 1 January 2021).

2. Johnson, N.; Mueller, J. Updating the accounts: Global mortality of the 1918-1920 "Spanish" influenza pandemic. Bull. Hist. Med. 2002, 76, 105-115. [CrossRef] [PubMed]

3. Carrat, F.; Flahault, A. Influenza vaccine: The challenge of antigenic drift. Vaccine 2007, 25, 6852-6862. [CrossRef] [PubMed]

4. Bouvier, N.M.; Palese, P. The biology of influenza viruses. Vaccine 2008, 26, D49-D53. [CrossRef]

5. Gong, J.; Fang, H.; Li, M.; Liu, Y.; Yang, K.; Liu, Y.; Xu, W. Potential targets and their relevant inhibitors in anti-influenza fields. Curr. Med. Chem. 2009, 16, 3716-3739. [CrossRef]

6. Takashita, E.; Meijer, A.; Lackenby, A.; Gubareva, L.; Rebelo-de-Andrade, H.; Besselaar, T.; Fry, A.; Gregory, V.; Leang, S.-K.; Huang, W.; et al. Global update on the susceptibility of human influenza viruses to neuraminidase inhibitors, 2013-2014. Antiviral Res. 2015, 117, 27-38. [CrossRef] [PubMed]

7. Wang, J.; Wu, Y.; Ma, C.; Fiorin, G.; Wang, J.; Pinto, L.H.; Lamb, R.A.; Klein, M.L.; DeGrado, W.F. Structure and inhibition of the drug-resistant S31N mutant of the M2 ion channel of influenza A virus. Proc. Natl. Acad. Sci. USA 2013, 110, 1315-1320. [CrossRef] [PubMed]

8. Copeland, C.S.; Doms, R.W.; Bolzau, E.M.; Webster, R.G.; Helenius, A. Assembly of influenza hemagglutinin trimers and its role in intracellular transport. J. Cell Biol. 1986, 103, 1179-1191. [CrossRef]

9. Boonstra, S.; Blijleven, J.S.; Roos, W.H.; Onck, P.R.; van der Giessen, E.; van Oijen, A.M. Hemagglutinin-mediated membrane fusion: A biophysical perspective. Ann. Rev. Biophys. 2018, 47, 153-173. [CrossRef]

10. Caton, A.J.; Brownlee, G.G.; Yewdell, J.W.; Gerhard, W. The antigenic structure of the influenza-virus A/PR/8/34 hemagglutinin (H1 subtype). Cell 1982, 31, 417-427. [CrossRef]

11. Seko, A.; Koketsu, M.; Nishizono, M.; Enoki, Y.; Ibrahim, H.R.; Juneja, L.R.; Kim, M.; Yamamoto, T. Occurrence of a sialylglycopeptide and free sialylglycans in hen's egg yolk. Biochim. Biophys. Acta Gen. Subj. 1997, 1335, 23-32. [CrossRef]

12. Liu, L.; Prudden, A.R.; Bosman, G.P.; Boons, G.-J. Improved isolation and characterization procedure of sialylglycopeptide from egg yolk powder. Carbohydr. Res. 2017, 452, 122-128. [CrossRef]

13. Suzuki, Y.; Nagao, Y.; Kato, H.; Suzuki, T.; Matsumoto, M.; Murayama, J.-I. The hemagglutinins of the human influenza viruses A and B recognize different receptor microdomains. Biochim. Biophys. Acta Biomembr. 1987, 903, 417-424. [CrossRef]

14. Gambaryan, A.; Tuzikov, A.; Chinarev, A.; Juneja, L.; Bovin, N.; Matrosovich, M. Polymeric inhibitor of influenza virus attachment protects mice from experimental influenza infection. Antiviral Res. 2002, 55, 201-205. [CrossRef]

15. Makimura, Y.; Watanabe, S.; Suzuki, T.; Suzuki, Y.; Ishida, H.; Kiso, M.; Katayama, T.; Kumagai, H.; Yamamoto, K. Chemoenzymatic synthesis and application of a sialoglycopolymer with a chitosan backbone as a potent inhibitor of human influenza virus hemagglutination. Carbohydr. Res. 2006, 341, 1803-1808. [CrossRef]

16. Wang, H.; Huang, W.; Orwenyo, J.; Banerjee, A.; Vasta, G.R.; Wang, L.X. Design and synthesis of glycoprotein-based multivalent glyco-ligands for influenza hemagglutinin and human galectin-3. Bioorg. Med. Chem. 2013, 21, 2037-2044. [CrossRef] [PubMed]

17. Tanaka, T.; Ishitani, H.; Miura, Y.; Oishi, K.; Takahashi, T.; Suzuki, T.; Shoda, S.-I.; Kimura, Y. Protecting-group-free synthesis of glycopolymers bearing sialyloligosaccharide and their high binding with the influenza virus. ACS Macro Lett. 2014, 3, 1074-1078. [CrossRef]

18. Murakami, M.; Okamoto, R.; Izumi, M.; Kajihara, Y. Chemical synthesis of an erythropoietin glycoform containing a complex-type disialyloligosaccharide. Angew. Chem. Int. Ed. Engl. 2012, 51, 3567-3572. [CrossRef] 
19. Huang, W.; Li, C.; Li, B.; Umekawa, M.; Yamamoto, K.; Zhang, X.; Wang, L.-X. Glycosynthases enable a highly efficient chemoenzymatic synthesis of N-glycoproteins carrying intact natural N-glycans. J. Am. Chem. Soc. 2009, 131, $2214-2223$. [CrossRef]

20. Huang, W.; Wang, D.N.; Yamada, M.; Wang, L.X. Chemoenzymatic synthesis and lectin array characterization of a class of N-glycan clusters. J. Am. Chem. Soc. 2009, 131, 17963-17971. [CrossRef] [PubMed]

21. Tang, F.; Yang, Y.; Tang, Y.; Tang, S.; Yang, L.; Sun, B.; Jiang, B.; Dong, J.; Liu, H.; Huang, M.; et al. One-pot N-glycosylation remodeling of IgG with non-natural sialylglycopeptides enables glycosite-specific and dual-payload antibody-drug conjugates. Org. Biomol. Chem. 2016, 14, 9501-9518. [CrossRef] [PubMed]

22. Wang, L.-X. Chemoenzymatic synthesis of glycopeptides and glycoproteins through endoglycosidase-catalyzed transglycosylation. Carbohydr. Res. 2008, 343, 1509-1522. [CrossRef]

23. Yamamoto, N.; Takayanagi, A.; Yoshino, A.; Sakakibara, T.; Kajihara, Y. An approach for a synthesis of asparagine-linked sialylglycopeptides having intact and homogeneous complex-type undecadisialyloligosaccharides. Chemistry 2007, 13, 613-625. [CrossRef]

24. Huang, W.; Ochiai, H.; Zhang, X.Y.; Wang, L.X. Introducing N-glycans into natural products through a chemoenzymatic approach Carbohydr. Res. 2008, 343, 2903-2913. [CrossRef] [PubMed]

25. Ogata, M.; Murata, T.; Murakami, K.; Suzuki, T.; Hidari, K.; Suzuki, Y.; Usui, T. Chemoenzymatic synthesis of artificial glycopolypeptides containing multivalent sialyloligosaccharides with a gamma-polyglutamic acid backbone and their effect on inhibition of infection by influenza viruses. Biorg. Med. Chem. 2007, 15, 1383-1393. [CrossRef]

26. Narla, S.N.; Sun, X.-L. Immobilized sialyloligo-macroligand and its protein binding specificity. Biomacromolecules 2012, 13, 1675-1682. [CrossRef] [PubMed]

27. Han, X.; Shi, Y.; Si, L.; Fan, Z.; Wang, H.; Xu, R.; Jiao, P.; Meng, K.; Tian, Z.; Zhou, X. Design, synthesis and biological activity evaluation of novel conjugated sialic acid and pentacyclic triterpene derivatives as anti-influenza entry inhibitors. MedChemComm 2016, 7, 1932-1945. [CrossRef]

28. Shi, Y.; Si, L.; Han, X.; Fan, Z.; Wang, S.; Li, M.; Sun, J.; Zhang, Y.; Zhou, D.; Xiao, S. Synthesis of novel pentacyclic triterpeneNeu5Ac2en derivatives and investigation of their in vitro anti-influenza entry activity. MedChemComm 2017, 8, $1531-1541$. [CrossRef]

29. Han, X.; Si, L.L.; Shi, Y.Y.; Fan, Z.B.; Wang, S.X.; Tian, Z.Y.; Li, M.; Sun, J.Q.; Jiao, P.X.; Ran, F.X.; et al. Synthesis and in vitro anti-influenza virus evaluation of novel sialic acid (C-5 and C-9)-pentacyclic triterpene derivatives. Molecules 2017, $22,1018$. [CrossRef] [PubMed]

30. Lacaille-Dubois, M.-A. Newest results on the chemistry and pharmacology of TCM drugs containing triterpene and steroid saponins. In Evidence and Rational Based Research on Chinese Drugs; Springer: Berlin/Heidelberg, Germany, 2013 ; pp. 87-135.

31. Jäger, S.; Trojan, H.; Kopp, T.; Laszczyk, M.N.; Scheffler, A. Pentacyclic triterpene distribution in various plants-rich sources for a new group of multi-potent plant extracts. Molecules 2009, 14, 2016-2031. [CrossRef] [PubMed]

32. Tung, N.H.; Kwon, H.-J.; Kim, J.-H.; Ra, J.C.; Kim, J.A.; Kim, Y.H. An anti-influenza component of the bark of Alnus japonica. Arch. Pharmacal Res. 2010, 33, 363-367. [CrossRef] [PubMed]

33. Song, G.; Yang, S.; Zhang, W.; Cao, Y.; Wang, P.; Ding, N.; Zhang, Z.; Guo, Y.; Li, Y. Discovery of the first series of small molecule H5N1 entry inhibitors. J. Med. Chem. 2009, 52, 7368-7371. [CrossRef]

34. Li, Y.; Jiang, R.; Ooi, L.S.; But, P.P.; Ooi, V.E. Antiviral triterpenoids from the medicinal plant Schefflera heptaphylla. Phytother. Res. 2007, 21, 466-470. [CrossRef]

35. Yu, M.; Si, L.; Wang, Y.; Wu, Y.; Yu, F.; Jiao, P.; Shi, Y.; Wang, H.; Xiao, S.; Fu, G. Discovery of pentacyclic triterpenoids as potential entry inhibitors of influenza viruses. J. Med. Chem. 2014, 57, 10058-10071. [CrossRef] [PubMed]

36. Tsuji, M.; Sriwilaijaroen, N.; Inoue, H.; Miki, K.; Kinoshita, K.; Koyama, K.; Furuhata, K.; Suzuki, Y.; Takahashi, K. Synthesis and anti-influenza virus evaluation of triterpene-sialic acid conjugates. Biorg. Med. Chem. 2018, 26, 17-24. [CrossRef]

37. Wang, H.; Xu, R.; Shi, Y.; Si, L.; Jiao, P.; Fan, Z.; Han, X.; Wu, X.; Zhou, X.; Yu, F. Design, synthesis and biological evaluation of novel L-ascorbic acid-conjugated pentacyclic triterpene derivatives as potential influenza virus entry inhibitors. Eur. J. Med. Chem. 2016, 110, 376-388. [CrossRef] [PubMed]

38. Xiao, S.; Si, L.; Tian, Z.; Jiao, P.; Fan, Z.; Meng, K.; Zhou, X.; Wang, H.; Xu, R.; Han, X. Pentacyclic triterpenes grafted on CD cores to interfere with influenza virus entry: A dramatic multivalent effect. Biomaterials 2016, 78, 74-85. [CrossRef] [PubMed]

39. Tian, Z.; Si, L.; Meng, K.; Zhou, X.; Zhang, Y.; Zhou, D.; Xiao, S. Inhibition of influenza virus infection by multivalent pentacyclic triterpene-functionalized per-O-methylated cyclodextrin conjugates. Eur. J. Med. Chem. 2017, 134, 133-139. [CrossRef]

40. Yang, Y.; He, H.-J.; Chang, H.; Yu, Y.; Yang, M.-B.; He, Y.; Fan, Z.-C.; Iyer, S.S.; Yu, P. Multivalent oleanolic acid human serum albumin conjugate as nonglycosylated neomucin for influenza virus capture and entry inhibition. Eur. J. Med. Chem. 2018, 143, 1723-1731. [CrossRef] [PubMed]

41. Mangasuli, S.N. Microwave assisted synthesis and biological activity of a novel triazino indole-coumarin hybrid: Crystal structure, hirshfeld surface analysis and DFT calculations. Chem. Data Collect. 2020, 29, 100503. [CrossRef]

42. Mahmoud, N.F.H.; El-Sewedy, A. Facile synthesis of novel heterocyclic compounds based on pyridine moiety with pharmaceutical activities. J. Heterocycl. Chem. 2020, 57, 1559-1572. [CrossRef]

43. Durmaz, M.; Halay, E.; Bozkurt, S. Recent applications of chiral calixarenes in asymmetric catalysis. Beilstein J. Org. Chem. 2018, 14, 1389-1412. [CrossRef] 
44. Franz, M.H.; Birzoi, R.; Maftei, C.V.; Maftei, E.; Kelter, G.; Fiebig, H.H.; Neda, I. Studies on the constituents of helleborus purpurascens: Analysis and biological activity of the aqueous and organic extracts. Amino Acids 2018, 50, 163-188. [CrossRef] [PubMed]

45. Franz, M.H.; Iorga, M.; Maftei, C.V.; Maftei, E.; Neda, I. Studies on the constituents of helleborus purpurascens: Use of derivatives from calix[6]arene, homooxacalix[3]arene and homoazacalix[3]arene as extractant agents for amino acids from the aqueous extract. Amino Acids 2020, 52, 55-72. [CrossRef] [PubMed]

46. Horatscheck, A.; Wagner, S.; Ortwein, J.; Kim, B.G.; Lisurek, M.; Beligny, S.; Schütz, A.; Rademann, J. Benzoylphosphonate-based photoactive phosphopeptide mimetics for modulation of protein tyrosine phosphatases and highly specific labeling of SH2 domains. Angew. Chem. Int. Ed. 2012, 51, 9441-9447. [CrossRef]

47. Zhu, T.; Xu, S.; Rahman, A.; Dogdibegovic, E.; Yang, P.; Pageni, P.; Kabir, M.P.; Zhou, X.D.; Tang, C. Cationic metallopolyelectrolytes for robust alkaline anion-exchange membranes. Angew. Chem. Int. Ed. Engl. 2018, 57, 2388-2392. [CrossRef] [PubMed]

48. Soriano del Amo, D.; Wang, W.; Jiang, H.; Besanceney, C.; Yan, A.C.; Levy, M.; Liu, Y.; Marlow, F.L.; Wu, P. Biocompatible copper(I) catalysts for in vivo imaging of glycans. J. Am. Chem. Soc. 2010, 132, 16893-16899. [CrossRef] [PubMed]

49. Sauter, N.K.; Bednarski, M.D.; Wurzburg, B.A.; Hanson, J.E.; Whitesides, G.M.; Skehel, J.J.; Wiley, D.C. Hemagglutinins from two influenza virus variants bind to sialic acid derivatives with millimolar dissociation constants: A 500-MHz proton nuclear magnetic resonance study. Biochemistry 1989, 28, 8388-8396. [CrossRef] [PubMed]

50. Li, J.; Yu, C.; Wang, R.; Xu, J.; Chi, Y.; Qin, J.; Liu, Q. The $\omega$-carboxyl group of 7-ketocholesteryl-9-carboxynonanoate mediates the binding of oxLDL to CD36 receptor and enhances caveolin-1 expression in macrophages. Int. J. Biochem. Cell Biol. 2017, 90, 121-135. [CrossRef] 